\title{
INVERSION OF ELECTRICAL RESISTIVITY SOUNDINGS FOR THE INVESTIGATION OF AQUIFERS IN THE ACARAÚ-ITAREMA REGION, CEARÁ, BRAZIL
}

\author{
José Marcio Lins Marinho ${ }^{1}$, Olivar Antônio Lima de Lima² and Sônia Maria Silva Vasconcelos ${ }^{3}$
}

\begin{abstract}
The main objectives of this study were to develop a robust scheme for the automatic inversion of electrical sounding measurements, and to perform a regional geoelectric reconnaissance survey for investigating the groundwater availability and quality in a 1,280 $\mathrm{km}^{2}$ sedimentary basin located in the Acaraú-Itarema region, Ceará, Brazil. An algorithm was developed for the automatic inversion of vertical electrical soundings (VESs) for the Schlumberger array of electrodes. The algorithm included the finite distances between the potential electrodes and uses the least absolutes method and the linearized Marquardt-Levenberg technique. The procedure was found to be more robust and efficient than the technique that uses the traditional least squares method. A total of 134 VESs were performed in the area. Ninety-six VESs are located in an area of major interest in this study. They were conducted on friable sedimentary rocks of the Barreiras Formation. Below the high resistivity cover, these electrical soundings show resistivities related to water-saturated layers that extend to the crystalline basement. Based on the inversion of the geoelectrical data and the information available a priori, summary maps were prepared to characterize the geometry of the aquifer system in the study area. The thickness of the aquifer varies from a few meters in the south to approximately 240 meters to the north. The permanent water reserve is estimated at $7.1 \times 10^{9} \mathrm{~m}^{3}$, with a renewable reserve of $4.0 \times 10^{8} \mathrm{~m}^{3} /$ year. Thus, a considerable water volume is available for exploitation in the area.
\end{abstract}

Keywords: geoelectrical soundings, groundwater, least absolute fitting.

RESUMO. Os principais objetivos deste trabalho foram o desenvolvimento de um esquema robusto para inverter dados de sondagens elétricas verticais, bem como realizar um levantamento geoelétrico regional para investigar a disponibilidade e qualidade dos recursos de água subterrânea, numa área sedimentar com 1.280 km², localizada na região de Acaraú-Itarema, Ceará, Brasil. Foi desenvolvido um algoritmo para inversão automática das sondagens elétricas verticais (SEVS), obtidas com 0 arranjo Schlumberger. Neste algoritmo estão incluídas as distâncias finitas entre os eletrodos de potencial. Foi usado o método dos mínimos absolutos e a técnica linearizada de Marquardt-Levenberg. Este procedimento mostrou-se mais robusto e eficiente que aquele obtido com o método tradicional dos mínimos quadrados. Um total de 134 sondagens elétricas foram executadas na área. Noventa e seis SEVs estão localizadas em área de maior interesse neste estudo. Foram executadas sobre rochas sedimentares friáveis pertencentes à Formação Barreiras. Abaixo de uma cobertura resistiva, estas sondagens elétricas apresentam resistividades compatíveis com camadas saturadas em água, que se estendem até o substrato cristalino. Baseados na inversão dos dados geoelétricos e nas informações a priori disponíveis, foram elaborados mapas sintéticos de caracterização geométrica do sistema aquífero na área de investigação. A espessura do aquífero varia de alguns metros no setor sul da área até aproximadamente $240 \mathrm{~m}$ no setor norte. A reserva permanente de água é estimada em $7,1 \times 10^{9} \mathrm{~m}^{3}$, com uma reserva renovável de $4,0 \times 10^{8} \mathrm{~m}^{3} / a n$. Assim, um volume hídrico considerável está disponível para a explotação na área.

Palavras-chave: sondagens elétricas, água subterrânea, ajuste por mínimos absolutos.

\footnotetext{
1 Universidade Federal do Ceará, Centro de Ciências (DEGE0/CC/UFC), Departamento de Geologia, Campus do Picí, Bloco 912, 60440-554 Fortaleza, CE, Brazil. Phone: +55(85) 3224-5001 / $99997-5780$ - E-mail: marcio.marinho@ufc.br

2 Universidade Federal da Bahia, Centro de Pesquisa em Geofísica e Geologia (CPGG/UFBA), Rua Barão de Jeremoabo s/n, Campus Universitário de Ondina, 40170-290 Salvador, BA, Brazil. Phone: +55(71) 3285-8597; Fax: +55(71) 3283-8501 - E-mail: olivar@ufba.br

3 Universidade Federal do Ceará, Centro de Ciências (DEGEO/CC/UFC), Departamento de Geologia, Campus do Picí, Bloco 912, 60440-554 Fortaleza, CE, Brazil. Phone: +55(85) 3224-2355 / 99998-0721 - E-mail: smaria@ufc.br
} 


\section{INTRODUCTION}

The region of Acaraú-Itarema, located in the northeastern portion of the Ceará state, Brazil, is included in the Semi-arid Polygon of the Brazilian Northeastern, and its main source of permanent water supply are the shaly-sandstone reservoirs of the Barreiras Formation. These deposits, of fluvial and marine origin, are characterized by a wide faciological variability, including sandstones, siltstones and mudstones, which comprizes both phreatic and confined aquifers components, of varied exploratory potentials. For such geological situations of almost sub-horizontal disposition, the vertical electrical sounding technique is a very appropriate approximation (Lima \& Santos, 2011; Lucena et al., 2013). Therefore, in order to implement a methodology for exploration of this complex aquifer system, the Ceará state, through its Technology Center (Núcleo de Tecnologia do Estado do Ceará) and the Federal University of Ceará (Universidade Federal do Ceará), were carried out one hundred and thirty-four Schlumberger electrical soundings during an assessment of the groundwater resources in the study region.

This investigation was motivated by $36 \mathrm{~m}^{3} / \mathrm{h}$ from a tubular well drilled near to the Itarema city. The objectives of the electrical resistivity survey were to determine the morphology of the crystalline substrate, the thickness of the overlying aquifers and their hydraulic characteristics.

Vertical electrical soundings (VESs) were conducted with maximum current electrode spacings $(A B / 2)$ ranging from $100 \mathrm{~m}$ to $1.5 \mathrm{~km}$. The least absolutes method was used with the linear Marquardt-Levenberg technique to invert VES data (Marinho \& Lima, 1995; Marinho, 1997). Based on the interpretation of the VESs and the available geological and hydrogeological information, maps were prepared of the crystalline basement topography, isopachs and the groundwater flow, and the permanent water reserve of the studied area was estimated.

\section{GEOLOGY}

Figure 1 shows the study area and its main access roads, the location of the VESs and the surface geology. The area covers approximately $1,280 \mathrm{~km}^{2}$. It is bounded to the west by the Acaraú River, to the east by the Aracatimirim River, to the north by the coastal plain and to the south by the rocks of the crystalline basement and the Serra Grande Formation. The topography is relatively flat and gently sloping with elevations that range from 10 to $20 \mathrm{~m}$ in altitude in the north and from 100 to $150 \mathrm{~m}$ in the south.

The general geology (NUTEC, 1988; CPRM, 2003) includes four main units: Precambrian gneisses, migmatites and my-
Ionites; Siluro-Devonian sandstones of the Serra Grande Formation; Tertiary-Quaternary sandy-clayey sedimentary rocks of the Barreiras Formation; and Quaternary alluvial sands and dunes.

The Quaternary sediments represent different geological environments than the clastic sediments of the Barreiras Formation; no electrical resistivity data are available for the Quaternary sediments, and they are not included in this study.

In the study area, the sediments of the Barreiras Formation are sandy or sandy-clayey, red to beige, and poorly sorted. The groundwater is stored in the sandy facies of this formation; defining the boundaries of the Barreiras aquifer, which is thicker than average in the northern portion of the study area (NUTEC, 1988), was the main objective of this study.

\section{HYDROGEOLOGY}

The Barreiras Formation is composed of Tertiary-Quaternary sedimentary cover over an impermeable crystalline basement. The basement outcrops in the southeast and southwest parts of the study area and has a thin altered mantle that represents a secondary groundwater aquifer. The Siluro-Devonian sandstones of the Serra Grande Formation, which have limited exposure in the southern part of the study area, do not exhibit water storage characteristics (NUTEC, 1988).

The water extracted from this sedimentary cover comes from its own storage. Thus, the direct groundwater recharge from rainfall called renewable reserve is crucial to the productivity of wells.

The renewable groundwater reserves were estimated based on the water balance equation and the surface of the study area. Because the area is flat and is covered by surface sands, the surface runoff was assumed to be zero. Evapotranspiration was estimated based on the Thornthwaite formula following the method of Vasconcelos (1994). The renewable reserves were estimated at $4.8 \times 10^{8} \mathrm{~m}^{3} /$ year.

Table 1 presents the characteristics of the aquifers based on fifteen tubular wells, whose locations are shown in Figure 1. The main aquifer in this study is the Barreiras Formation (Fig. 1). Most of the wells drilled south of the latitude of the Marco city to obtain groundwater in this formation reach the crystalline basement in less than $60 \mathrm{~m}$, but to the north, only well I or 4IT-01-CE (Fig. 1) reached the crystalline basement at a depth of $156 \mathrm{~m}$. Wells $\mathrm{L}, \mathrm{M}$, and $\mathrm{N}$, which are located near the Itarema city, were 121, 148.7 and $149.3 \mathrm{~m}$ deep, respectively, and did not reach the crystalline basement. The initial analysis indicated that the sediments in these wells are similar to those of the Barreiras Formation.

The hydraulic transmissivity values obtained from pumping tests range from $5.0 \times 10^{-5}$ to $7.5 \times 10^{-3} \mathrm{~m}^{2} / \mathrm{s}$ (Table 1). The three 


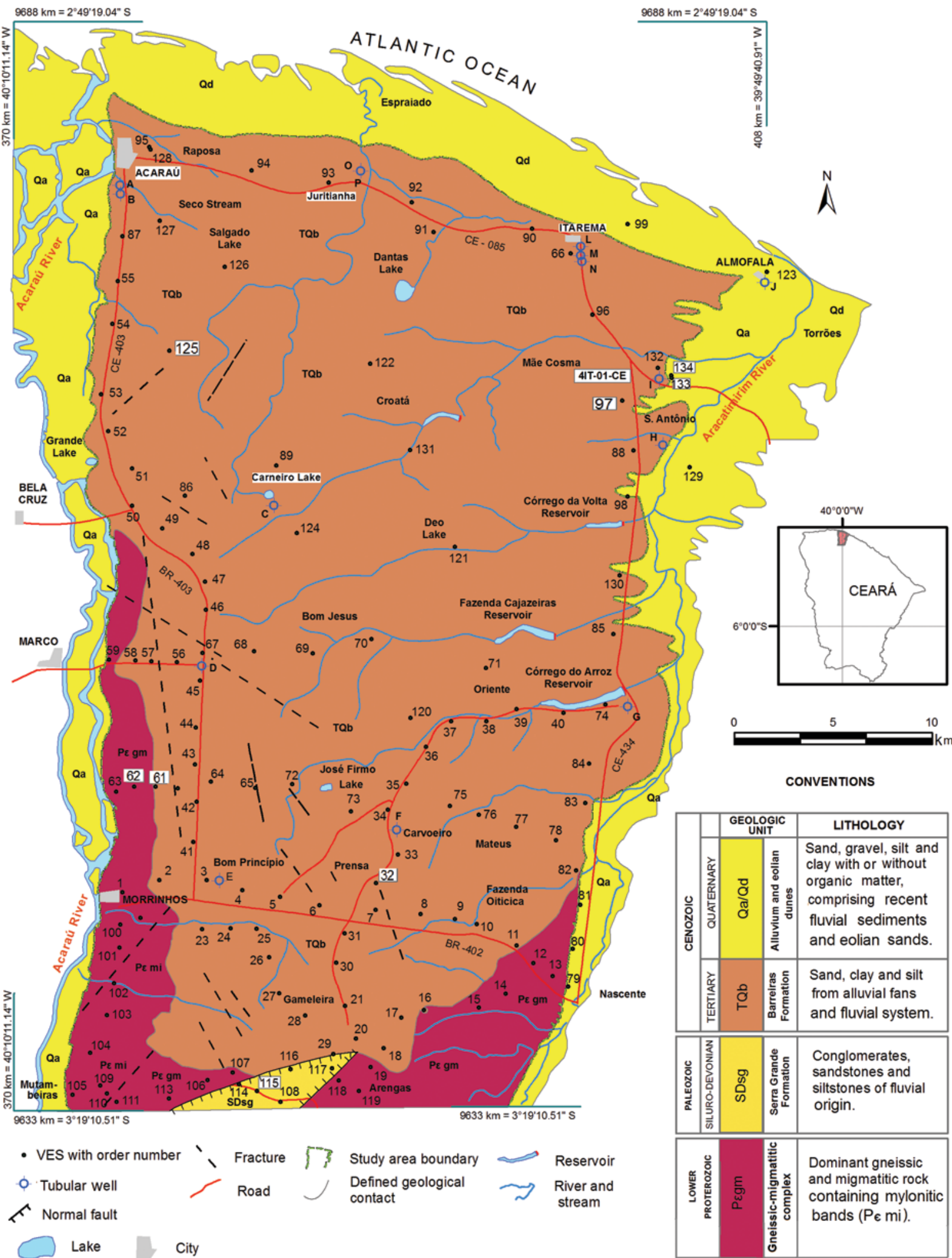

Figure 1 - Simplified geological map of the study area (adapted from Nutec, 1988 and CPRM, 2003), including the location of electrical soundings and tubular wells. 
Table 1 - Aquifer characteristics based on tubular wells.

\begin{tabular}{|c|c|c|c|c|c|c|c|c|c|c|c|c|c|}
\hline \multirow[b]{2}{*}{ Ord. } & \multirow[b]{2}{*}{ Location } & \multirow[b]{2}{*}{ City } & \multirow[b]{2}{*}{ Code } & \multirow[b]{2}{*}{ Date } & \multirow{2}{*}{$\begin{array}{c}\text { Depth } \\
\text { (m) }\end{array}$} & \multirow{2}{*}{$\begin{array}{l}\text { S.L. } \\
\text { (m) }\end{array}$} & \multirow{2}{*}{$\begin{array}{l}\text { D.L. } \\
\text { (m) }\end{array}$} & \multirow{2}{*}{$\begin{array}{l}\text { Sat. Thick. } \\
\text { (m) }\end{array}$} & \multirow{2}{*}{$\begin{array}{c}Q \\
\left(\mathrm{~m}^{3} / \mathrm{h}\right)\end{array}$} & \multirow{2}{*}{$\begin{array}{c}\mathrm{K} \\
(\mathrm{m} / \mathrm{s})\end{array}$} & \multirow{2}{*}{$\begin{array}{c}\mathrm{T}_{\mathrm{r}} \\
\left(\mathrm{m}^{2} / \mathrm{s}\right)\end{array}$} & \multicolumn{2}{|c|}{ Water Quality } \\
\hline & & & & & & & & & & & & $\begin{array}{l}\text { Electrical cond. } \\
(\mathrm{S} / \mathrm{m})\end{array}$ & $\begin{array}{c}\text { TDS } \\
(\mathrm{mg} / \mathrm{l})\end{array}$ \\
\hline $\bar{A}$ & Acaraú & Acaraú & ACA-01 & 1995 & 82.5 & 2.5 & 28.0 & 79.9 & 50.0 & $8.0 \mathrm{E}-05$ & $6.4 \mathrm{E}-03$ & 0.0266 & 160 \\
\hline$B$ & Acaraú & Acaraú & ACA-02 & 09/15/95 & 83.6 & 1.6 & 20.0 & 81.9 & 80.0 & $8.7 \mathrm{E}-05$ & $7.1 \mathrm{E}-03$ & 0.0297 & 178 \\
\hline$C$ & L. do Carneiro & Acaraú & LCA-01 & 09/02/93 & 72.0 & 11.7 & 12.4 & 60.3 & 10.0 & $1.0 \mathrm{E}-04$ & $7.5 \mathrm{E}-03$ & 0.1074 & 644 \\
\hline$D$ & T. do Marco & Marco & TRI-01 & 01/13/94 & 60.0 & 14.7 & 35.0 & 42.0 & 4.3 & $1.3 \mathrm{E}-06$ & 5.5E-05 & 0.0621 & 376 \\
\hline$E$ & Bom Princípio & Morrinhos & B0M-02 & - & 41.0 & 20.6 & 23.1 & - & 5.0 & $2.5 \mathrm{E}-06$ & $5.0 \mathrm{E}-05$ & 0.1985 & 1191 \\
\hline$F$ & Carvoeiro & Itarema & CAR-02 & 01/06/94 & 60.0 & 10.1 & 35.0 & - & 2.5 & $1.2 \mathrm{E}-06$ & $6.1 \mathrm{E}-05$ & 0.0986 & 592 \\
\hline $\mathrm{G}$ & C. do Arroz & Itarema & - & - & - & - & - & - & 14.6 & - & - & 0.0315 & 450 \\
\hline $\mathrm{H}$ & S. Antônio & Itarema & - & 1987 & 54.0 & - & - & - & 6.0 & - & - & - & - \\
\hline 1 & Mãe Cosma & Itarema & 4IT-01-CE & 03/08/94 & 158.0 & 15.2 & 91.7 & 140.8 & 14.4 & - & - & 0.2500 & 1534.7 \\
\hline $\mathrm{J}$ & Almofala & Itarema & ALF-01 & 11/25/93 & 91.0 & 5.0 & 40.0 & 83.4 & 17.0 & $1.9 \mathrm{E}-06$ & $1.6 \mathrm{E}-04$ & 0.0825 & 495 \\
\hline $\mathrm{L}$ & Itarema & Itarema & PT-01/84 & 02/23/84 & 121.0 & 4.4 & 24.0 & 116.0 & 36.0 & $1.3 \mathrm{E}-05$ & $1.4 \mathrm{E}-03$ & 0.0700 & 280 \\
\hline$M$ & Itarema & Itarema & PT-02/91 & $06 / 30 / 91$ & 148.7 & 4.2 & 27.0 & 144.5 & 25.6 & $8.0 \mathrm{E}-06$ & $1.1 \mathrm{E}-03$ & - & - \\
\hline $\mathrm{N}$ & Itarema & Itarema & PT-01/91 & 07/06/91 & 149.3 & 3.9 & 26.6 & 145.4 & 25.6 & $8.0 \mathrm{E}-06$ & $1.2 \mathrm{E}-03$ & 0.0463 & 231 \\
\hline 0 & Juritianha & Acaraú & JUR-01 & 02/13/93 & 78.0 & 2.6 & 14.6 & 75.0 & 20.0 & $2.3 \mathrm{E}-05$ & $1.8 \mathrm{E}-03$ & 0.1353 & 811 \\
\hline$P$ & Juritianha & Acaraú & JUR-02 & - & 57.0 & 3.6 & 12.7 & 53.0 & 10.0 & $9.8 \mathrm{E}-06$ & $5.3 \mathrm{E}-04$ & 0.1439 & 936 \\
\hline
\end{tabular}

Ord. = order; S.L. = static level; D.L. = dynamic level; Sat. Thick. = saturated thickness; $Q=$ flow rate; $K=$ hydraulic conductivity; $T_{r}=$ transmissivity; Electrical cond. = electrical conductivity; TDS = total dissolved solids.

transmissivity values from south of the Marco city are the lowest in the area. The transmissivities are higher to the north of Marco, particularly at wells $A$ and $B$, which were drilled near the Acaraú city, and well C, which is located near Carneiro Lake.

Well 4IT-01-CE (Fig. 2) provides information about the subsurface geology and the main information for the interpretation of the electrical soundings. The geophysical profiles of the well provide complementary lithological information (Fig. 2) to the information obtained from samples. In particular, the gamma ray $\log$ is useful for distinguishing between sands and clays. The aquifer sediments in the well extend from the static level $(15.2 \mathrm{~m})$ to the top of the crystalline basement at $156 \mathrm{~m}$. In summary, the well profile consists of poorly consolidated clastic sediments that range from clean sands to clayey sandstones with interbedded ferruginous sandstones.

\section{Inversion of Resistivity Data}

A Schlumberger field curve is composed of several segments with overlapping sections, and a restriction is set for the ratio of the distance between the potential electrodes and the distance between the current electrodes ( $M N<A B / 5)$. Traditionally, the segmented Schlumberger curve is processed and reduced to a continuous curve using several procedures (Deppermann, 1954; Kunetz, 1966; Zohdy, 1989). The processed Schlumberger curve is typically digitized at a logarithmic interval equal to the interval of the filter used in the solution algorithm of the direct onedimensional problem. The main purpose of digitizing the curve is to decrease the computation time. Thus, after it is reduced to a continuous and digitized curve, the Schlumberger field curve can be interpreted in terms of a horizontally stratified model. Computer programs with these characteristics have been developed by Koefoed (1979), Lima (1989), and Zohdy \& Bisdorf (1989).

Rijo et al. (1977) provided another approach to this problem. To retain the accuracy of the field data, the authors did not process the field curve but rather interpreted it directly. Thus, the MN distance is included in the direct problem solution for stratified media, so the apparent Schlumberger resistivity is calculated from the potentials in electrodes $\mathrm{M}$ and $\mathrm{N}$ and not from the electrical field at the middle of the potential electrodes. This approach doubles the computation time but provides greater versatility to field work because the MN distance restriction is reduced to $\mathrm{MN}<\mathrm{AB}$.

\section{The Direct One-dimensional Problem}

The solution for the direct one-dimensional problem used in this study is identical to that proposed by Rijo et al. (1977) and can be summarized as follows. The potential $V(r, \mathbf{P})$ at a distance 


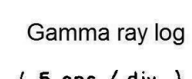

( $5 \mathrm{cps} / \mathrm{div}$ )

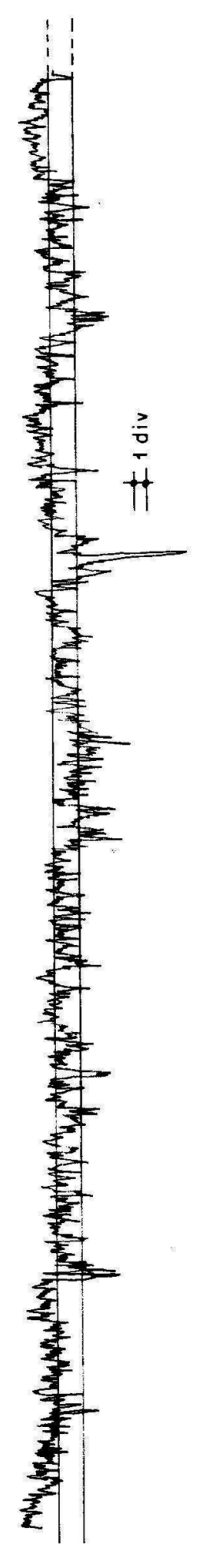

Lithological profile

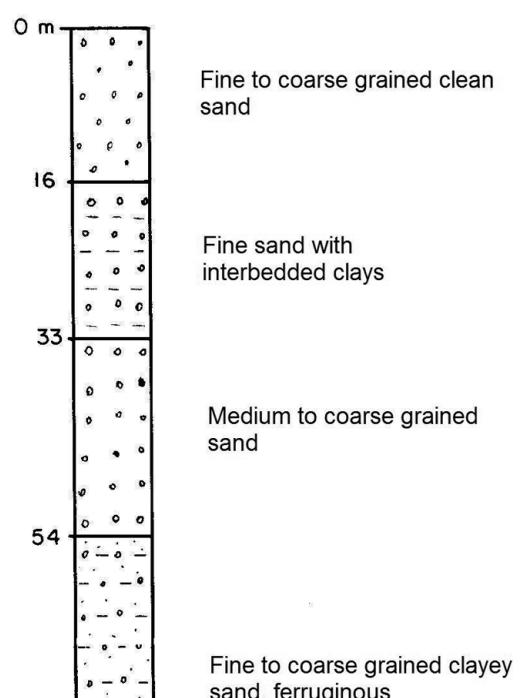

sand, ferruginous

Figure 2 - Lithological profile, gamma ray log and electrical resistivity log of well 4-IT-01-CE.

$r$ from a point source $I$ on a surface of a horizontally stratified terrane is given by the relationship (Koefoed, 1979; Parasnis, 1986):

$$
V(r, \mathbf{P})=\frac{I}{2 \pi} \int_{0}^{\infty} T(\lambda, \mathbf{P}) J_{0}(\lambda, r) d \lambda
$$

where $J_{0}$ is the Bessel function of the first kind and zero order, and $T$ is the transform of the apparent resistivity function, which

\section{Electrical resistivity log}

Single pole ( $2.5 \mathrm{ohm} / \mathrm{div}$ )

o. Top of

$10-$

$20-$

$30-$

$40-$

50-

$60-$

70-

80-

90-

$100-$

$110-$

$120-$

130-

$140-$

150-

-

$-$

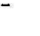

Cataclasite

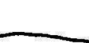


which is written in discrete form as:

$$
V(r, \mathbf{P})=\frac{I}{2 \pi r} \sum_{j=1}^{n c} T\left(e^{n_{j}-\ln r}, \mathbf{P}\right) c\left(\eta_{j}\right)
$$

where $n c$ is the number of coefficients of the filter, and $\eta_{j}$ and $c\left(\eta_{j}\right)$ are the abscissa and coefficients of the filter, respectively. The $c\left(\eta_{j}\right)$ coefficients of the filter can be found in Sandberg (1979), Rijo (1995), and Guptasarma \& Singh (1997).

For symmetrical arrangements, the apparent resistivity is given by:

$$
\rho_{a}=2 \pi \frac{r_{1} r_{2}}{\left(r_{2}-r_{1}\right) I}\left[V\left(r_{1}, \mathbf{P}\right)-V\left(r_{2}, \mathbf{P}\right)\right]
$$

where $r_{1}=A M=A B / 2-M N / 2$, and $r_{2}=A N=$ $A B / 2+M N / 2$.

Combining Eqs. (2) and (3) gives:

$$
\begin{aligned}
\rho_{a}= & \frac{r_{2}}{r_{2}-r_{1}} \sum_{i=1}^{n c} T\left(e^{n_{i}-\ln r_{1}}, \mathbf{P}\right) c\left(\eta_{i}\right) \\
& -\frac{r_{1}}{r_{2}-r_{1}} \sum_{j=1}^{n c} T\left(e^{n_{j}-\ln r_{1}}, \mathbf{P}\right) c\left(\eta_{j}\right)
\end{aligned}
$$

This study used Eq. (4) and the coefficients from Rijo (1995).

\section{The Inverse One-dimensional Problem}

The Marquardt-Levenberg technique, or chain regression technique, was applied by Inman (1975) and Rijo et al. (1977) in the inversion of electrical sounding data using the traditional method of least squares. The main modification in our approach concerns the minimization method, which also leads to changes in the application of the chain regression technique (Marinho \& Lima, 1995; Marinho, 1997).

The least absolutes formulation, which is presented here for vertical electrical soundings, consists of minimizing the objective function:

$$
Q(\mathbf{P})=\sum\left|R C(\mathbf{P})_{i}-R O_{i}\right|
$$

where $R C(\mathbf{P})_{i}$ is the apparent resistivity function calculated for the $P$ parameters at the $i$-th observation point from a set of n points, $R O_{i}$ is the apparent resistivity observed at that point, $P=\left(P_{1}, P_{2}, \ldots, P_{m}\right)$ is the parameter vector (resistivities and thicknesses of the layers), and $n>m$.

In the linear inversion, the apparent resistivity function $\mathrm{RC}$ in Eq. (5) is expanded in a Taylor series around the initial parameters $P^{o}=\left(P_{1}^{o}, P_{2}^{o}, \ldots, P_{m}^{o}\right)$, and the power terms greater than one are discarded. Eq. (5) can then be written as follows:

$$
Q(P)=\sum_{i=1}^{n}\left|R C_{i}^{o}+\sum_{j=1}^{m} A_{j i}^{o} \Delta P_{j}-R O_{i}\right|
$$

where $R C_{i}^{o}=R C\left(P^{o}\right)_{i}, A_{i j}^{o}=\partial R C(\mathbf{P})_{i} /\left.\partial P_{j}\right|_{P^{o}}$, and $\Delta P_{j}=P_{j}-P_{j}^{o}$.

Taking the partial derivative of Eq. (6) with respect to $\Delta P_{k}$ and making it equal to zero, the basic equations are obtained after manipulation:

$$
\begin{aligned}
& \sum_{i=1}^{n} \frac{\sum_{j=1}^{m} A_{i k}^{o} A_{i j}^{o} \Delta P_{j}}{\left|R C_{i}^{o}-R O_{i}+\sum_{j=1}^{m} A_{i j}^{o} \Delta P_{j}\right|} \\
= & \sum_{i=1}^{n} \frac{A_{i k}^{o}\left(R O_{i}-R C_{i}^{o}\right)}{\left|R C_{i}^{o}-R O_{i}+\sum_{j=1}^{m} A_{i j}^{o} \Delta P_{j}\right|}
\end{aligned}
$$

The matrix representation of $\mathrm{Eq} .(7)$ is:

$$
\mathbf{A}^{T} \mathbf{F A} \Delta \mathbf{P}=\mathbf{A}^{T} \mathbf{F} \Delta \boldsymbol{\rho}_{a}
$$

where $\mathbf{A}$ is the sensitivity matrix, $\mathbf{A}^{T}$ is its transposed matrix, $\Delta \mathbf{P}=\left(\Delta P_{1}, \Delta P_{2}, \ldots, \Delta P_{m}\right)$ is the parameter variation vector, $\Delta \boldsymbol{\rho}_{a}$ is the vector of the difference between the observed and calculated apparent resistivities, and $\mathbf{F}$ is a diagonal matrix $n \times n$, which is given by:

$$
F_{i}=\frac{1}{\left|R C_{i}^{o}-R O_{i}+\sum_{j=1}^{m} A_{i j}^{o} \Delta P_{j}\right|}
$$

A natural iterative scheme for the $L_{1}$ solution of Eq. (8) is to take the residuals from the previous model in the $\mathbf{F}$ matrix (Scales et al., 1988; Scales \& Smith, 1994). This approach was called iteratively reweighted least squares.

The solution of Eq. (8) in each iteration is:

$$
\Delta \mathbf{P}=\left(\mathbf{A}^{T} \mathbf{F A}\right)^{-1} \mathbf{A}^{T} \mathbf{F} \Delta \boldsymbol{\rho}_{a}
$$

The following algorithm was used to increase the stability of the inverse of Eq. (10) and ensure convergence from poor initial models:

$$
\Delta \mathbf{P}=\left(\mathbf{A}^{T} \mathbf{F} \mathbf{A}+k \mathbf{I}\right)^{-1} \mathbf{A}^{T} \mathbf{F} \Delta \boldsymbol{\rho}_{a}
$$

where $k$ is the Marquardt-Levenberg or damping factor, and $I$ is the identity matrix (Dimri, 1992). By analogy with the damped least squares method, the expression damped least absolutes was used for this approach.

Because the apparent resistivity function has strictly positive values, the logarithmic difference is the best estimator of the deviation. Thus, the problem was reparametrized in logarithmic form. Other advantages for the inversion of resistivity data in 
logarithmic space were given by Rijo et al. (1977), Hoversten et al. (1982) and Simms \& Morgan (1990).

The estimated data error is given by the formula:

$$
E=\frac{Q}{n} .
$$

Three additional aspects of the inversion algorithm should be addressed before interpreting the VESs. The first concerns the value of the $F_{i}$ denominator in Eq. (9), which is approximated by the absolute value of the difference between the calculated and observed resistivity values. This value in the logarithmic space is taken as $\geq 0.00001$.

The second aspect refers to the calculation of the sensitivity matrix, which is analytically performed here in logarithmic space by the relationship:

$$
A_{i j}=\frac{P_{j}}{\rho_{a}(L)_{i}} \cdot \frac{\partial \rho_{a}(L)_{i}}{\partial P_{j}}
$$

where $L=A B / 2$. In this sense, the parameters do not need to be formally logarithmized in the inversion procedures in the logarithmic space; only the apparent resistivity logarithms are taken.

The third aspect is related to the comparison between the algorithm formulated in this study with the least absolutes method and the traditional technique, which is formulated with the least squares method (e.g., Rijo et al., 1977). By analyzing theoretical data or noise-contaminated data, we conclude that the algorithm that minimizes the $L_{1}$ norm is more robust than the algorithm that minimizes the $L_{2}$ norm (Marinho \& Lima, 1995; Marinho, 1997, 2010). This algorithm has been used with good performance in other studies (e.g., Marinho \& Vasconcelos, 2004; Marinho et al., 2005, 2006).

\section{Interpretation of VESs}

The issue of inherent ambiguity in geophysical interpretation has been studied for decades (Roy, 1962) and it is still a current issue. The ambiguity in interpreting VESs is addressed here with the equivalence of solutions. In principle, the model with the fewest layers that adequately reflects the geological information should be chosen as the VES solution (Menke, 1984; Simms \& Morgan, 1992).

The equivalence of solutions refers to the fact that more than one set of geoelectrical parameters, even sets with the same number of parameters, can be a technically acceptable solution. This issue is addressed here based on the efficiency of the inversion algorithm that corresponds to the robustness of the solution. The calculation of the solution by inversion was tested using theoretical electrical sounding curves or curves contaminated by artificial noise. These tests showed better recovery using the damped least absolutes method than using the conventional method of damped least squares (Marinho \& Lima, 1995; Marinho, 1997).

Each VES was initially interpreted for a multi-layer model according to Zohdy \& Bisdorf (1989). Based on this interpretation and on available a priori information, i.e., the geologic mapping, the data on water table in fifteen wells, the lithologic logs of these wells and geophysical log of one well, an initial model was obtained and the final interpretation was performed using the Resel program (Marinho, 2010) according to the damped least absolutes formulation presented here, which usually resulted in a solution with less than 6 iterations.

\section{Parametric or Benchmark Soundings}

Because the crystalline basement is the substrate for the entire study area, knowledge of its resistivity is important; thus, the soundings on crystalline terranes are parametric. The analysis of the VESs on the crystalline basement or where it is shallow showed that the resistivity of the ascending parts of the curves of this class have a log-normal distribution between 250 and 4,000 ohm.m, with an mean of 1,200 ohm.m. Due to the large study area and the wide range of resistivity values of the unaltered basement, these statistical results were only used for reference.

Crossed electrical soundings 133 and 134 were conducted near to the tubular well 4IT-01-CE (Fig. 1), which penetrated $156 \mathrm{~m}$ of sedimentary rocks and reached the crystalline basement. These VESs are considered to be benchmarks. The thicknesses were set based on the geological and geophysical log profiles (Fig. 2); subsequently, the automatic interpretations of these VESs were performed and are shown in Figures 3 and 4. The results of this benchmarking are excellent and suggest a model for the entire northern portion of the area. The interpretation results of VESs 133 and 134 are very similar; small differences may be related to the fact that the centers of the soundings are $60 \mathrm{~m}$ apart. A relatively high resistivity layer (approximately $65 \mathrm{ohm} . \mathrm{m}$ ) is interpreted as the center of the saturated zone.

\section{Classification of VESs}

The 134 VESs can be divided into three classes that correspond to the different geoelectrical and geological environments in the area. The VESs of the first group comprise 34 curves for the crystalline basement terranes or where the basement is shallow. 


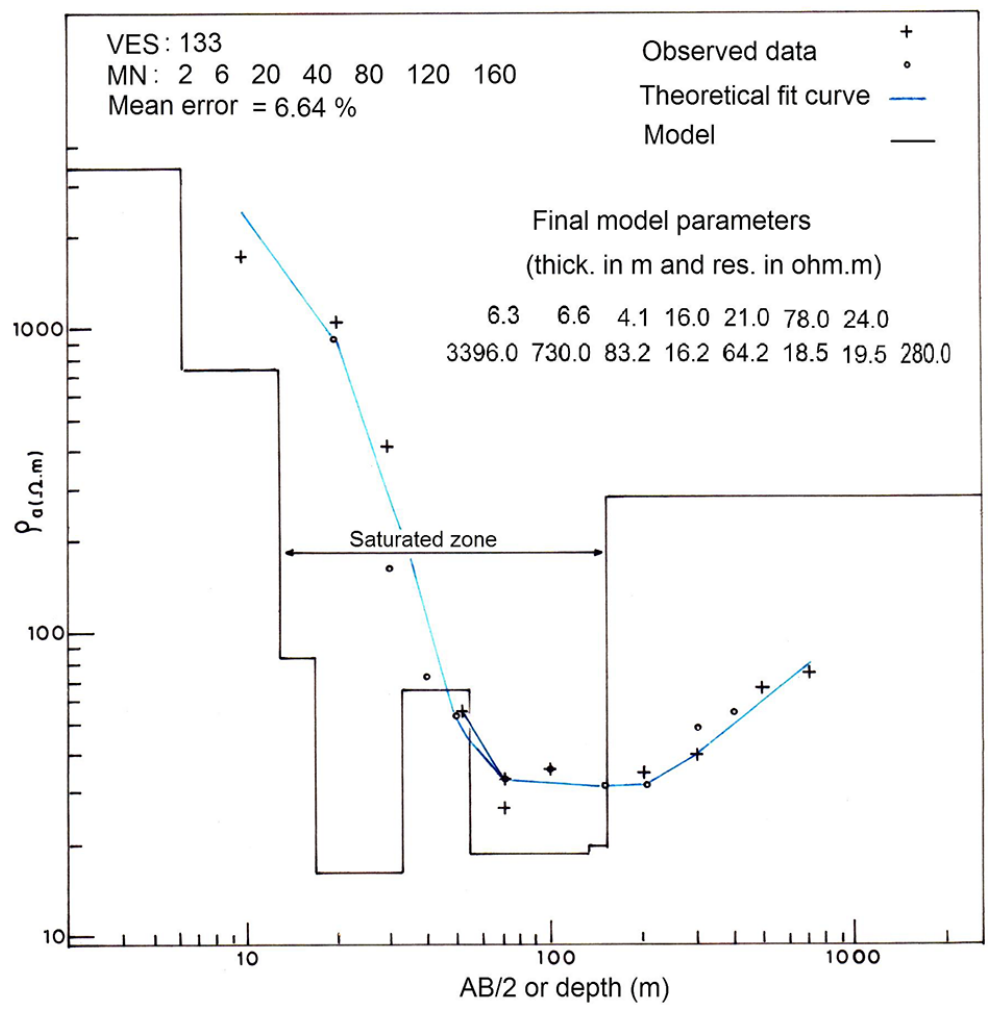

Figure 3 - Benchmark electrical sounding along tubular well 4-IT-01-CE. The thicknesses were set, and the resistivity values were obtained by automatic inversion.

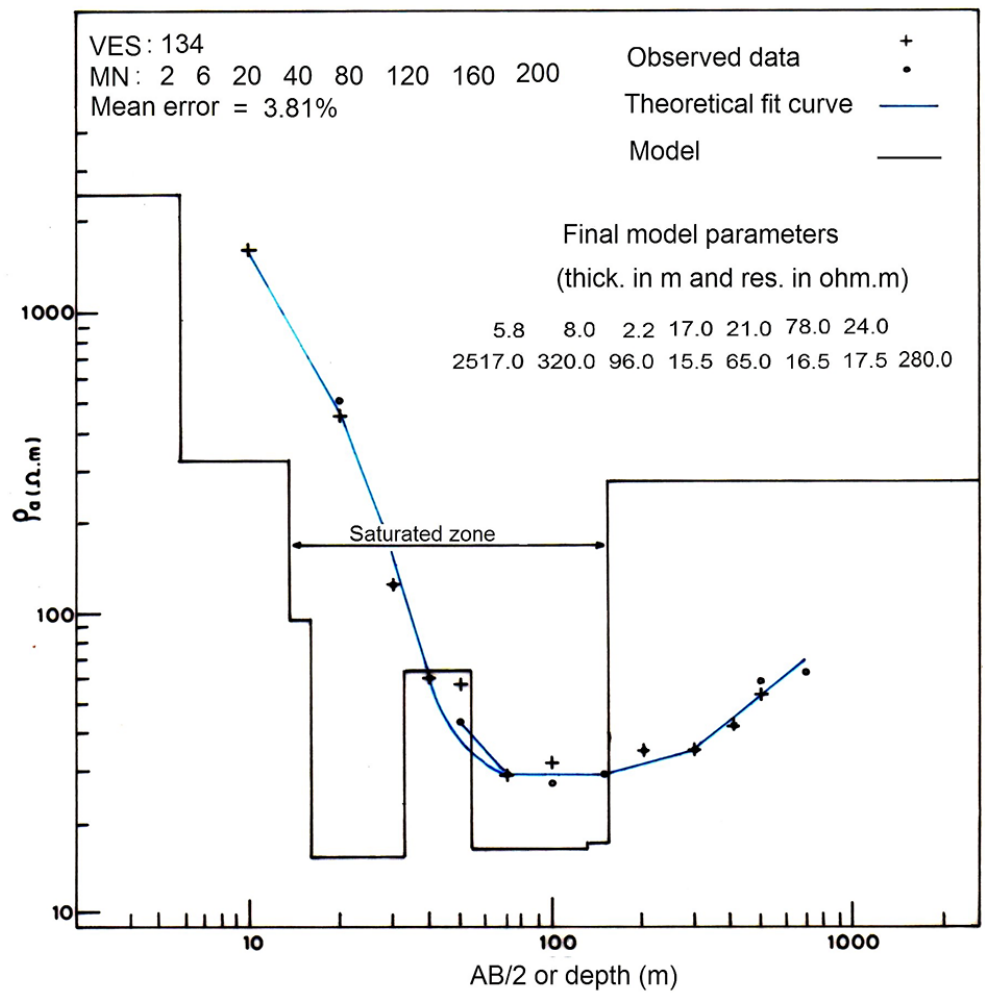

Figure 4 - Benchmark electrical sounding along tubular well 4-IT-01-CE crossed with VES133. The resistivity values were obtained by automatic inversion. 
VES62 (Fig. 5) is characteristic of this environment; it exhibits a resistive-conductive-resistive layered sequence, in which the conductive layer corresponds to a shallow aquifer that is most likely composed of altered gneiss. The interpretation approach obtained resistivity values of $368.6,12.3$, and $249.6 \mathrm{ohm} . \mathrm{m}$ for the three layers, and the thicknesses were 0.7 and $9.0 \mathrm{~m}$. A and HA type curves are also present in this class. The water storage conditions in this environment are distinct and restricted, but the water levels can be correlated with the groundwater levels from neighboring sedimentary terranes.

Four class 2 VESs were performed on very resistive sandstones of the Serra Grande Formation. Figure 6 shows VES 115 related to this class. The class 2 VESs did not reach the crystalline basement for the maximum AB/2 of $200 \mathrm{~m}$. The lowest resistivity value obtained in the interpretation of the VESs of this class was $140 \mathrm{ohm} . \mathrm{m}$, and there is no information about the groundwater in this restricted area.

Ninety-six VESs were performed on unconsolidated or poorly consolidated clastic, sandy or sandy-clayey sediments, which were sometimes ferruginous, of the Barreiras Formation; all these VESs were grouped into class 3. These soundings show one or more high resistivity surface layers that correspond to soils, sands or dry clayey sands; they also end with a high resistivity layer that corresponds to the crystalline basement. Below the resistive cover, the curves of this class show water-saturated layers that extend to the crystalline basement; these layers are composed of sands, clayey sands or sandy clays. The curves of this class are of major interest for our study.

The Figures 7 and 8 show representative class 3 electrical sounding field curves. VESs 32 and 61 (Fig. 7) are representative of the VESs located south of the latitude of the Marco city. Curve 32 is a $Q H$ type curve, and 61 is a $K H$ type curve. The $Q$ and $H$ components, which were calculated for $A B / 2$ values of less than $72 \mathrm{~m}$, are interpreted to correspond to the aquifers. The $\mathrm{K}$ component, which was calculated for $A B / 2$ values of less than $15 \mathrm{~m}$, corresponds to a dry high resistivity layer. The crystalline basement in this region is more than $60 \mathrm{~m}$ deep.

North of the Marco city, the VESs need the maximum AB/2 distance of up to $1,500 \mathrm{~m}$ to reach the crystalline basement. This means that the thickness of the sedimentary package increases toward the coast. VESs 97 and 125, which are shown in Figure 8 , are representative of this range. They are classified as HKHA and HKH curves, respectively; the $\mathrm{K}$ component in curves 97 and 125 , for $A B / 2$ of approximately 100 and $70 \mathrm{~m}$, respectively, is interpreted as a relatively high resistivity layer that most likely corresponds to the most promising range for groundwater extraction.

\section{Interpretation of Another Representative Class 3 Electrical Sounding}

Figure 9 shows the interpretation of VES 97 , which was shown in Figure 8. VES 97 is located approximately $2.5 \mathrm{~km}$ southwest of well 4IT-01-CE. The depth to the top of the resistive basement was estimated to be $186 \mathrm{~m}$, and the groundwater level was at approximately $8 \mathrm{~m}$. Layers 2, 3, 4 and 5 are located between a high resistivity surface layer and another high resistivity layer that corresponds to the crystalline basement. Of the saturated layers, layer 3 stands out as being relatively resistive within the saturated conductive sediments and must thus be composed by sands. Layer 3 corresponds to the $\mathrm{K}$ component of the curve and is estimated to extend from depths of 28 to $62 \mathrm{~m}$.

\section{VES Results}

In the study area, where the multi-layer aquifer is located between a high resistivity surface layer and the crystalline basement, the mean resistivity was adopted as being representative of the middle aquifer at each electrical sounding site by taking into account the role of the resistivity component normal to the stratification plane, which is called the transverse resistivity (Carrasquilla \& Rijo, 1991; Marinho, 1997). The thickness was assumed to be equal to the sum of the thicknesses of the saturated strata.

Several maps were prepared based on the interpretation of the VESs, including an isopach map of the aquifer (Fig. 10). The necessary data from each VES point are the depth of the water table and the thickness of the saturated zone that overlies the high resistivity basement. The isopach values increase gradually from the southern part of the study area to the northern part on the coast and reach approximately $240 \mathrm{~m}$.

The permanent water reserve of the aquifer, which is also called the static or geological reserve, can be estimated using the isopach map and knowledge of the effective porosity. This reserve represents the groundwater volume potentially stored below the static level surface. The total volume of the saturated zone, which is the volume between the piezometric surface and the surface of the crystalline basement, is needed to calculate this reserve and can be estimated from the isopach map. The areas of two consecutive isopachs were calculated and multiplied by the corresponding mean saturated thickness, which provides the saturated volume between the two isopachs. The sum of these volumes gives the total saturated volume, which was estimated at $1.19 \times 10^{11} \mathrm{~m}^{3}$.

The total saturated volume is multiplied by the mean effective porosity of the aquifer to obtain the permanent reserve volume. We have no information about the effective porosity of the aquifer in the study area, which is a critical problem. Fetter (2001) provides a table in which the effective porosity of 


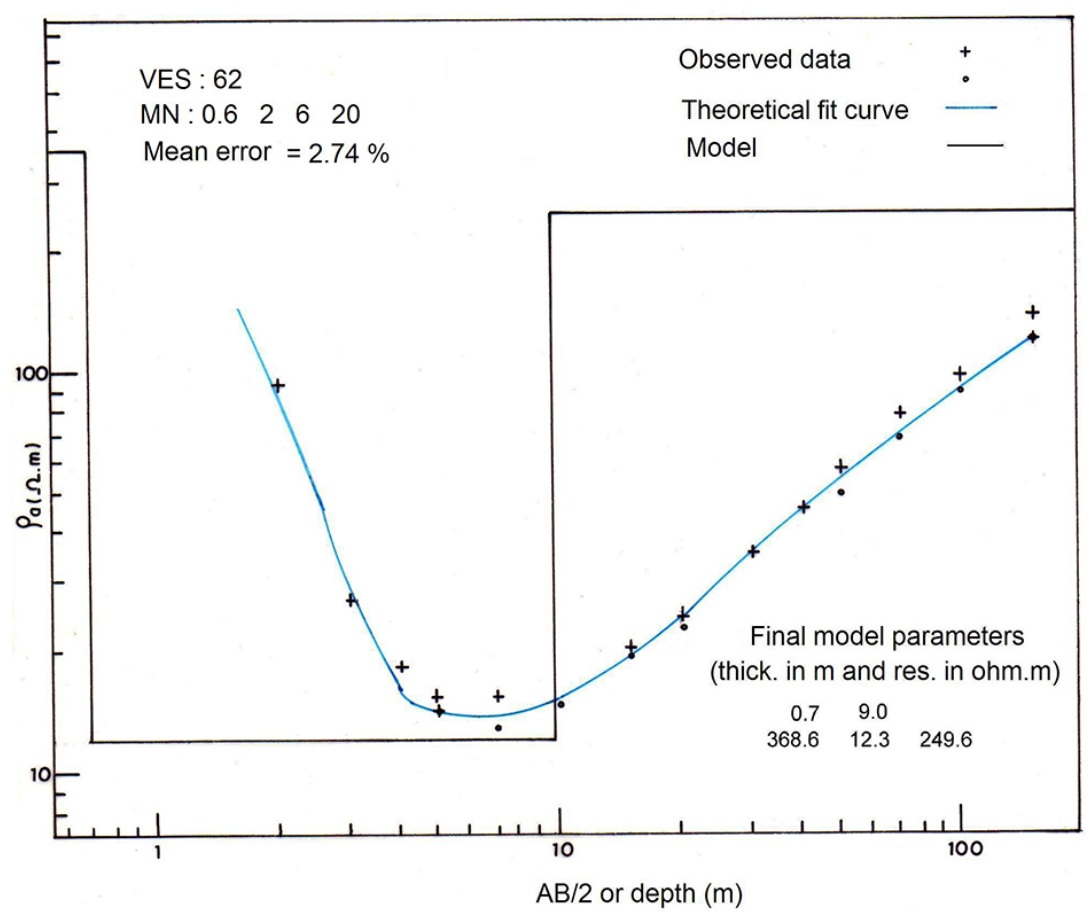

Figure $\mathbf{5}$ - Interpretation of a class 1 VES in the crystalline terrane. The curve is a type $\mathrm{H}$ curve, and the second layer represents the aquifer. The bedrock is approximately $10 \mathrm{~m}$ deep.

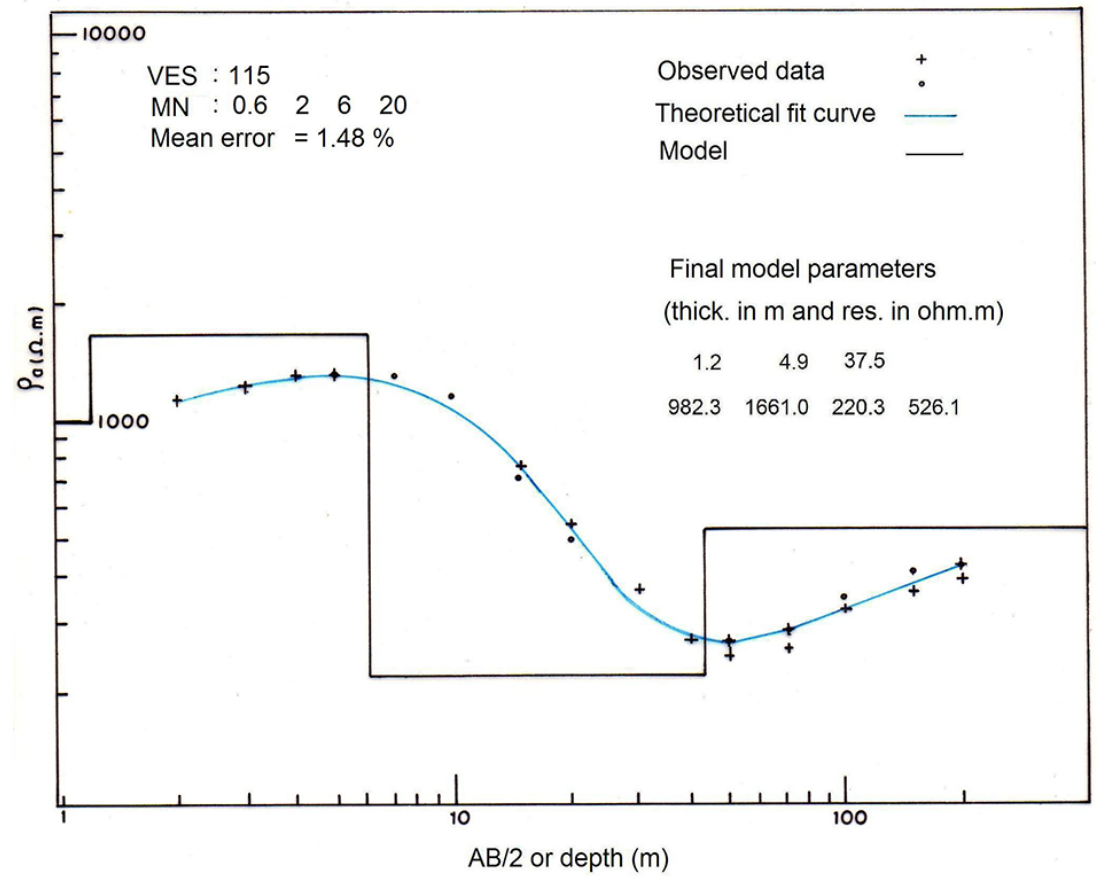

Figure 6 - Interpretation of a class 2 VES in the Serra Grande Formation showing a sequence of high resistivity sandstones. The crystalline basement was not reached. 


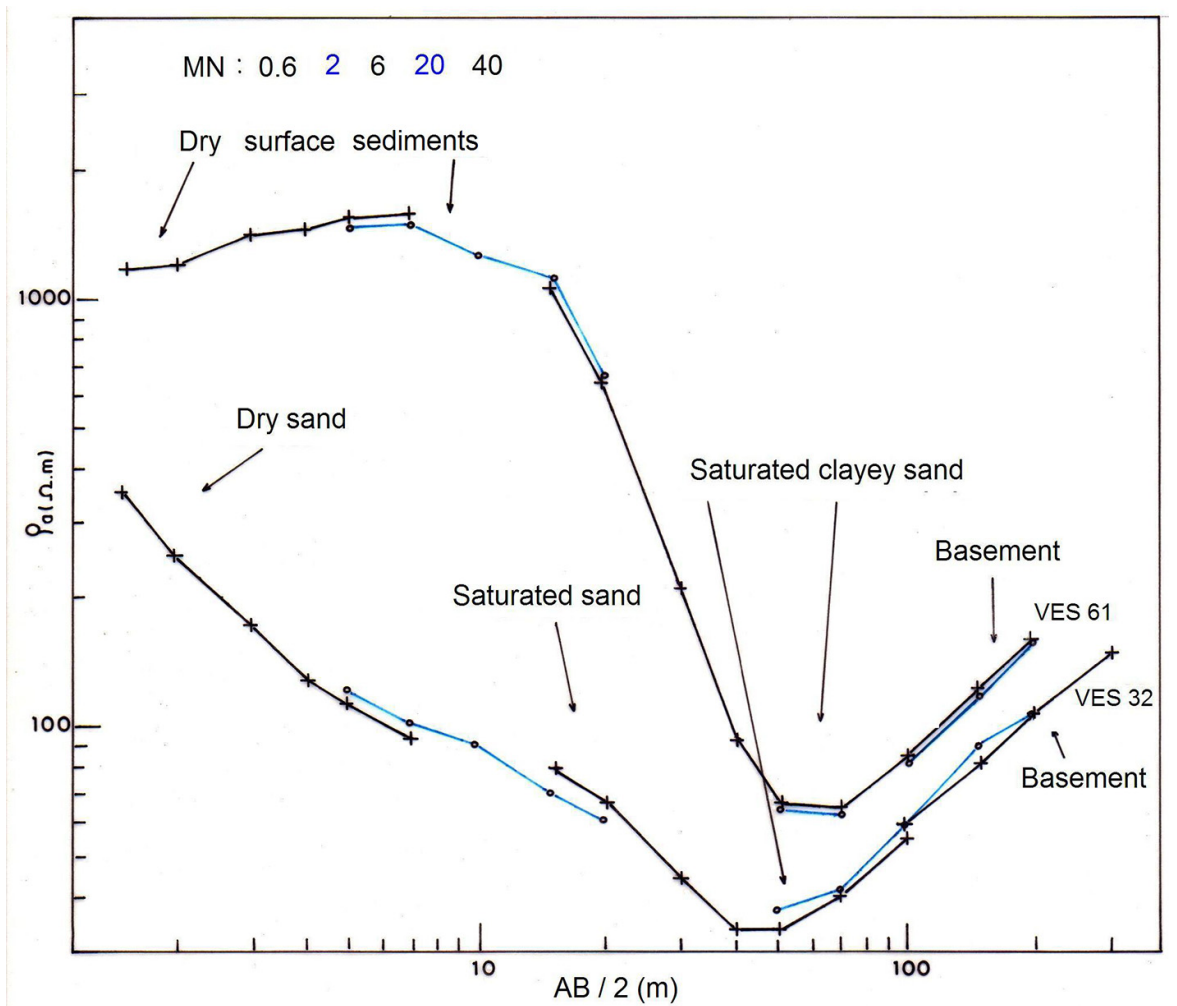

Figure 7 - Class 3 electrical sounding field curves. The $Q$ and $\mathrm{H}$ components of the curves are aquifers. The crystalline basement is more than $60 \mathrm{~m}$ deep.

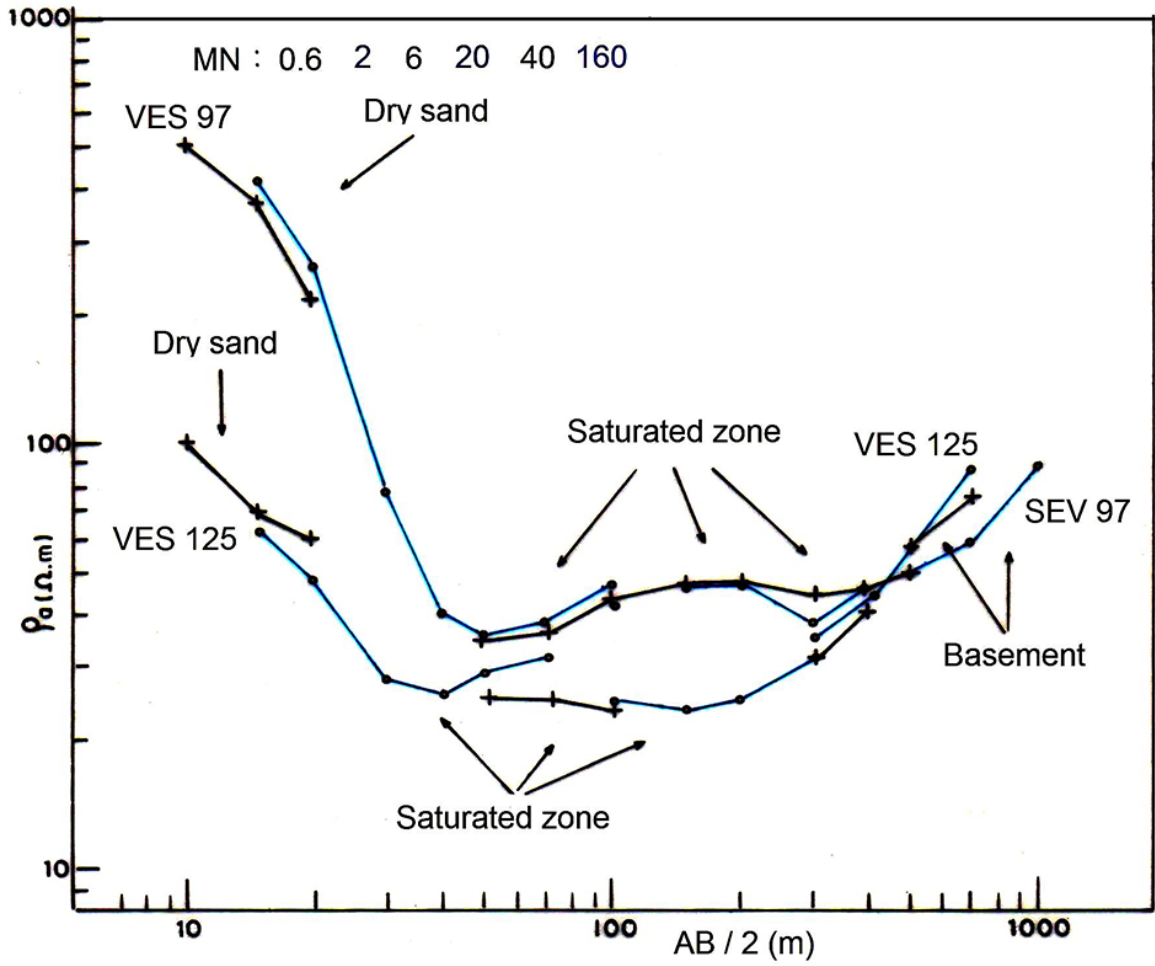

Figure 8 - Class 3 electrical sounding field curves. The aquifer is multi-layered and contains a high resistivity layer. The basement is more than $100 \mathrm{~m}$ deep. 


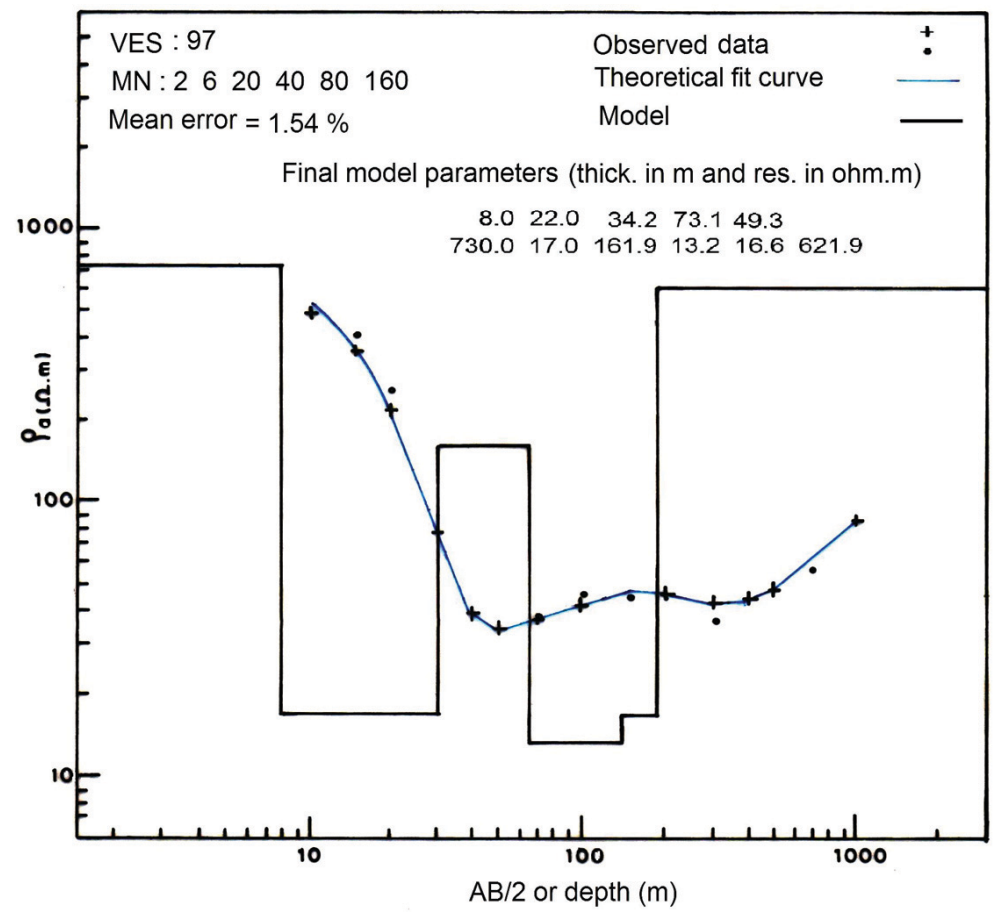

Figure 9 - Interpretation of a typical class 3 electrical sounding field curves in the Barreiras Formation in the northern part of the study area. Layers 2, 3, 4 and 5 are interpreted as being saturated, and layer 3 is particularly resistive. The depth of the high resistivity basement was estimated at $186 \mathrm{~m}$.

sandy clays ranges from 0.03 to 0.12 , with a mean of 0.07 . By adopting an effective porosity of 0.06 for the entire study area, the water reserve is estimated to be $1.19 \times 10^{11} \times 0.06=$ $7.1 \times 10^{9} \mathrm{~m}^{3}$

The piezometric map was plotted based on the results of the VES interpretations, and flow lines were traced on it (Fig. 11). The map shows that the groundwater flows toward the Acaraú River in the western portion of the study area, toward the Aracatimirim River in the eastern portion of the study area, and toward the coast in the northern section. The combination of the saturated thickness map (Fig. 10) with the piezometric map (Fig. 11) indicates areas with good prospects for groundwater, which are the areas where the piezometric curves are widely spaced and the saturated aquifer is thickest. Using this criterion, the entire area north of the latitude of Bela Cruz is favorable, which is confirmed by data from previously drilled tubular wells.

\section{CONCLUSIONS}

Electrical resistivity studies, combined with a priori information, i.e., the geologic mapping and the data on water tubular wells, were used to delineate the aquifer zone within the study area. The aquifer system is a free aquifer system with water tables that can be correlated between sedimentary and crystalline terranes. The aquifer medium is multi-layered and contains mostly sands and clayey sands with no clay layers that cause significant confinement. The substrate of the aquifer zone is composed of high resistivity crystalline rocks and is overlain by an unconsolidated high resistivity layer.

Two benchmark soundings helped to define a geoelectrical model that was widely used over a large part of the study area, especially in the northern portion, where the wells are better spatially distributed in the study area.

MN distances are included in the electrical sounding interpretation scheme, which allows the $\mathrm{MN}<\mathrm{AB} / 5$ restriction to be removed; as a result, the accuracy of the potential difference measurements was improved. The damped least absolutes method was used in the VES inversions, which provided more robust results than the conventional damped least squares method.

The results of the study indicate the following:

(a) The groundwater catchment appears to be good north of Marco because the estimated transmissivities range from medium to high. After this investigation, two wells drilled in the area, including one in Itarema and one in Acaraú, exhibited flow rates of 75 and $100 \mathrm{~m}^{3} / \mathrm{h}$, respectively, which confirms the results of this study. The groundwater catchment is less favorable south of Marco because the transmissivities were estimated to be less than $1.0 \times 10^{-3} \mathrm{~m}^{2} / \mathrm{s}$; 


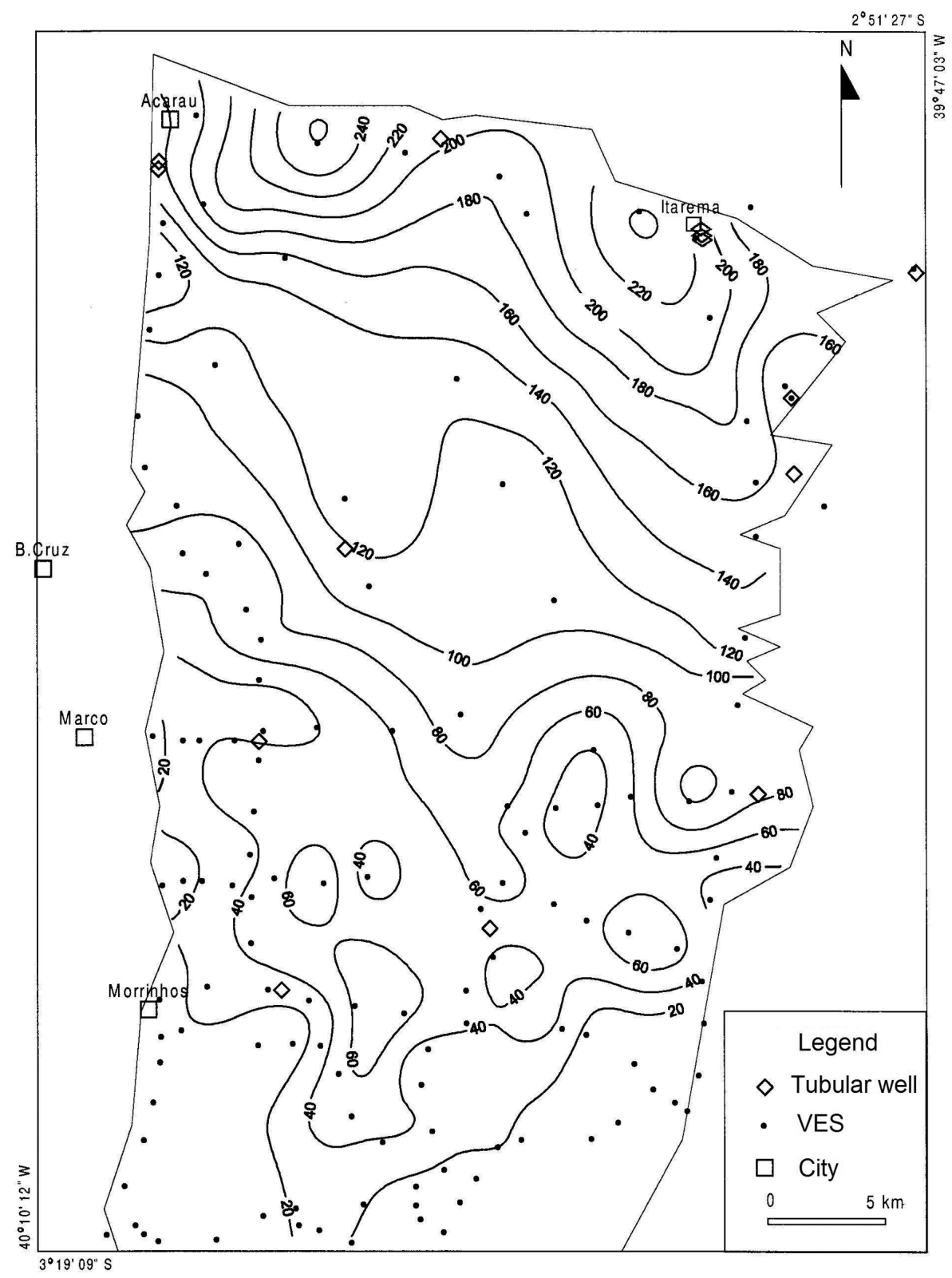

Figure $\mathbf{1 0}$ - Isopach map of the aquifer sediments. Contours in meters.

(b) The renewable water reserves for the study area were estimated at $4.0 \times 10^{8} \mathrm{~m}^{3} / \mathrm{year}$, and the permanent reserves were estimated at $7.1 \times 10^{9} \mathrm{~m}^{3}$, which indicates that a considerable volume of groundwater can be exploited through tubular wells or other methods of extraction.

\section{ACKNOWLEDGEMENTS}

We thank the Departamento de Geologia, Centro de Ciências, Universidade Federal do Ceará (DEGEO/CC/UFC) and the Centro de Pesquisa em Geofísica e Geologia, Universidade Federal da Bahia (CPGG/UFBa) for supporting this study. Olivar A.L. de Lima thanks CNPq for the support through a research grant.

\section{REFERENCES}

CARRASQUILLAA \& RIJO L. 1991. Análise da teoria convencional dos meios estratificados na interpretação de SEVs da Ilha do Marajó-Pará. Brazilian Journal of Geophysics, 9(2): 211-222.

CPRM - Companhia de Pesquisa de Recursos Minerais. 2003. Mapa Geológico do Ceará, Escala 1/500.000, Fortaleza-Ceará, Brazil. 


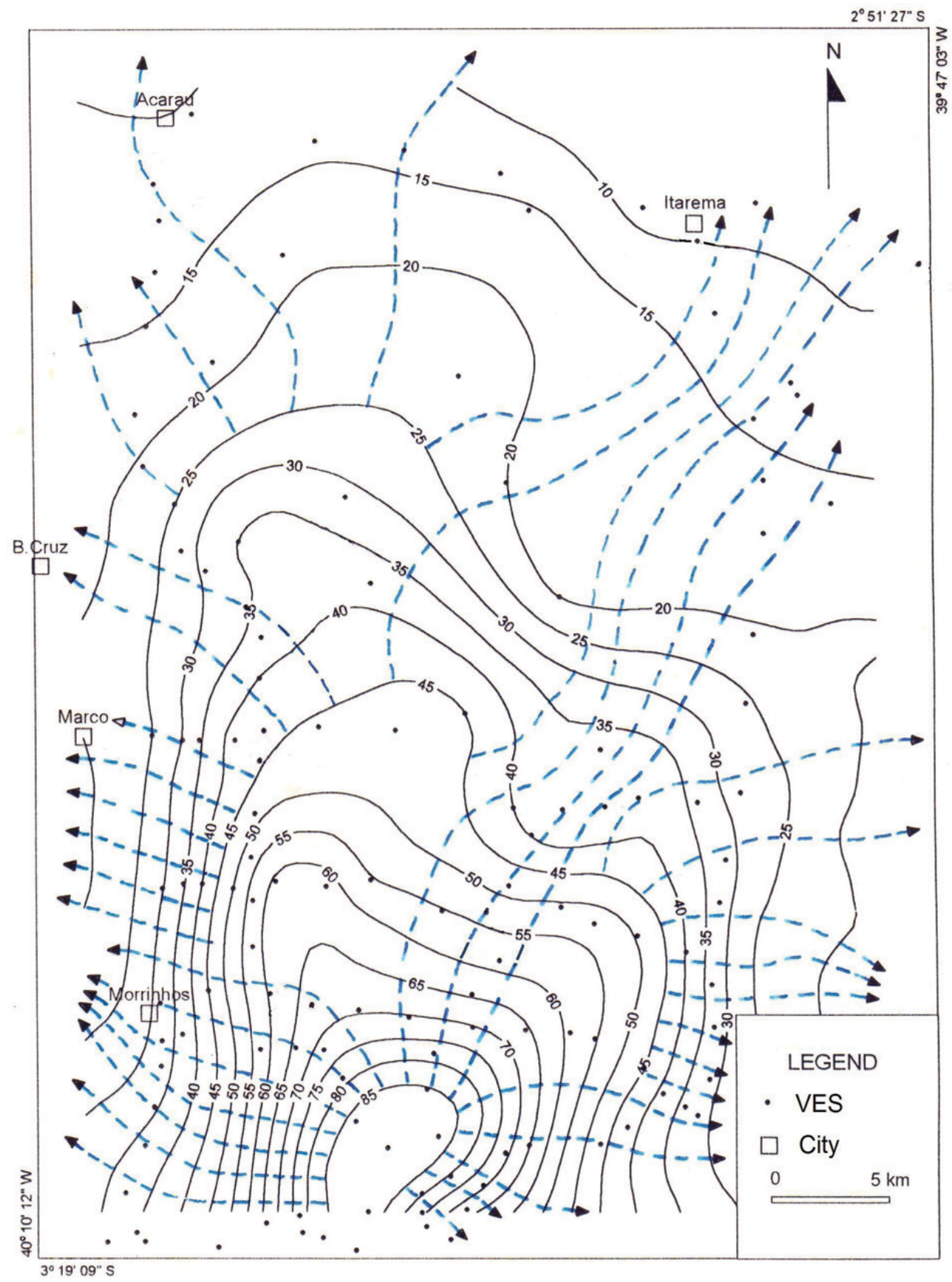

Figure 11 - Piezometric map with dashed flow lines. Contours in meters.

DEPPERMANN K. 1954. Die Abhängigkeit des scheinbaren Widerstandes vom Sondenabstand bei der Vierpunkt-Methode. Geophys. Prosp., 2: 262-273.

DIMRI V. 1992. Deconvolution and inverse theory: application to geophysical problems. Elsevier Sci. Pub., Amsterdam, 230 pp.

FETTER CW. 2001. Applied Hydrogeology. Macmillan, New York, 598 pp. GHOSH DP. 1971. The application of filter theory to the direct interpre- tation of geoelectrical resistivity measurements. Geophys. Prosp., 19: 192-217.

GUPTASARMA D \& SINGH B. 1997. New digital linear filters for Hankel $J_{0}$ and $J_{1}$ transforms. Geophys. Prosp., 45: 745-762.

HOVERSTEN GM, DEY A \& MORRISON HF. 1982. Comparison of five least-squares inversion techniques in resistivity sounding. Geophys. Prosp., 30: 688-715. 
INMAN JR. 1975. Resistivity inversion with ridge regression. Geophysics, 40: 798-817.

KOEFOED 0. 1979. Geosounding Principles, 1. Resistivity Sounding Measurements. Methods in Geochemistry and Geophysics, 14A, Elsevier, Amsterdam, 272 pp.

KUNETZ G. 1966. Principles of direct current resistivity prospecting. Gebrüder Borntraeger, Berlin, 103 pp.

LIMA OAL. 1989. SEVSCHL: programa para modelagem e inversão de dados de sondagem elétrica vertical. CPGG, Universidade Federal da Bahia, Salvador, Bahia, Brazil.

LIMA OAL \& SANTOS ESM. 2011. Caracterização geológica e geofísica do sistema aquífero Urucuia e de seu substrato nas bacias dos rios Arrojado e Formoso, Bahia. Brazilian Journal of Geophysics, 29(4): 723-744.

LUCENA LRF, OLIVEIRA Jr. JGO, MEDEIROS WE \& QUEIROZ MA. 2013. The potential of the Barreiras aquifer in the lower course of the Doce River, Rio Grande do Norte State, Northeast Brazil - Integration of hydrogeological and geophysical data. Brazilian Journal of Geophysics, 31(1): 43-57.

MARINHO JML. 1997. Inversões de sondagens de eletrorresistividade com ap licação ao estudo de aquíferos clásticos na região Acaraú-Itarema, Ceará. Ph.D. Thesis, Programa de Pós-Graduação em Geofísica, Universidade Federal da Bahia, Brazil. 173 pp.

MARINHO JML. 2010. Resel: programa em Visual Basic para modelagem e inversão de dados de Sondagem Elétrica Vertical (SEV), arranjo Schlumberger. Departamento de Geologia, Universidade Federal do Ceará, Brazil.

MARINHO JML \& LIMA OAL. 1995. Inversão de dados de sondagem elétrica minimizando a norma L1. In: International Congress of the Brazilian Geophysical Society, 4., Rio de Janeiro, Expanded Abstract, SBGf, Brazil, v. II, 1007-1009.

MARINHO JML \& VASCONCELOS SMS. 2004. Bacia costeira do Rio Cauípe, Caucaia, Ceará: Levantamentos Geoelétrico e Hidrogeológico. Revista de Geologia, 17(1): 22-37.

MARINHO JML, VASCONCELOS SMS \& SOUZA ML. 2005. Hidrogeofísica da faixa costeira entre Caucaia e Paracurú - Ceará - Brasil. In: International Congress of the Brazilian Geophysical Society, 9., SalvadorBA, Expanded Abstract, SBGf, Brazil, CD-ROM.

MARINHO JML, VASCONCELOS SMS \& SOUZA ML. 2006. Hidrogeofísica da faixa costeira entre Caucaia e Paracurú - Ceará. Revista de Geologia, 19(2): 224-238.
MENKE W. 1984. Geophysical data analysis: Discrete inverse theory. Academic Press, Florida, USA, 260 pp.

NUTEC - Núcleo de Tecnologia do Estado do Ceará. 1988. Levantamento geofísico e hidrogeológico da região entre Itarema e Acaraú-CE. Internal Report, v. 1, 2, Fortaleza, Ceará, Brazil.

PARASNIS DS. 1986. Principles of Applied Geophysics. Chapman and Hall, London and N.Y., 402 pp.

RIJO L. 1995. Programa SEV1D2P para interpretação de SEV - Schlumberger. Electrical Geophysics Software Library (EGSLIB), DGF/UFPA.

RIJO L, PELTON WH, FEITOSA EC \& WARD SH. 1977. Interpretation of apparent resistivity data from Apodi Valley, Rio Grande do Norte, Brazil. Geophysics, 42: 811-822.

ROY A. 1962. Ambiguity in Geophysical Interpretation. Geophysics, 27: 90-99.

SANDBERG S. 1979. Documentation and analysis of Schlumberger iterative 1-D inversion. Work performed under Contract no. DE-AC07-79 ET/27002, Department of Geology and Geophysics, University of Utah, USA.

SCALES JA \& SMITH ML. 1994. Introductory Geophysical Inverse Theory. Samizdat Press, Colorado, USA, 183 pp.

SCALES JA, GERZTENKORN A, TREITEL S \& LINES LR. 1988. Robust optimization in geophysical inverse theory. In: Intern. Meet. Soc. Expl. Geophys., 58., Anaheim, USA, vol. II, 827-830.

SIMMS JE \& MORGAN FD. 1990. Re-evaluation of Pekeris' onedimensional resistivity interpretation method. First Break, 8: 130-136.

SIMMS JE \& MORGAN FD. 1992. Comparison of four least-squares inversion schemes for studying equivalence in one-dimensional resistivity interpretation. Geophysics, 57: 1282-1293.

VASCONCELOS SMS. 1994. Estimativa da recarga subterrânea a partir do balanço hídrico - exemplo de Fortaleza-CE. Revista de Geologia, 7: $27-34$.

ZOHDY AAR. 1989. A new method for the automatic interpretation of Schlumberger and Wenner sounding curves. Geophysics, 54: 245-253.

ZOHDY AAR \& BISDORF RJ. 1989. Programs for the automatic processing and interpretation of Schlumberger sounding curves in QuickBASIC 4.0. U.S.G.S., Open-File Report, 89-137-B.

Recebido em 24 setembro, 2015 / Aceito em 9 março, 2016

Received on September 24, 2015 / Accepted on March 9, 2016 


\section{NOTES ABOUT THE AUTHORS}

José Marcio Lins Marinho is a geologist (1965) from the Universidade Federal de Pernambuco and B.S. in Mathematics (1980) from the Universidade Federal do Ceará (UFC). M.Sc. (1977) and Ph.D. (1977) in Geophysics from Universidade Federal da Bahia. From 1967 to 1997 was full professor at the Geology Department of UFC, working in crystallography, mineralogy, applied geophysics and geostatistics. Currently, works in electrical resistivity for underground water and geological research. Also is a software developer in vertical electrical sounding to geological studies, especially for groundwater research and electrical grounding.

Olivar Antônio Lima de Lima received a B.S. (1967) and a M.Sc. (1970) in Geology from the Universidade Federal do Rio de Janeiro and a Ph.D. (1979) in Geophysics from the Universidade Federal da Bahia (UFBA). Was a postdoctoral fellow (1989-1990) with the Department of Petroleum Engineering at the University of Texas, Austin. Since 1969 has worked as a research geophysicist and is a retired titular professor at the Center for Research in Geophysics and Geology of UFBA. Research interests include application of electromagnetic methods for oil and groundwater exploration, environmental problems and physical properties of rocks. Founder member of the SBGf.

Sônia Maria Silva Vasconcelos is a geologist graduated in 1974 from the Universidade Federal do Ceará, received a B.S. in Physics from the Universidade Federal do Rio Grande do Norte (1979), specialization in Hydrogeology (1986) and M.Sc. in Civil Engineering, Water Resources (1989) in the Universidade Federal do Ceará; Ph.D. in Geosciences, Hydrogeology in Universidade de São Paulo (1999), Pos-doc in Geoestatistics in Instituto Superior Técnico/Universidade de Lisboa (2008). Currently, works as Associate Professor in the Departamento de Geologia, Centro de Ciências da Universidade Federal do Ceará since 1983. Areas of interest: Groundwater flow, Geostatistics and Geophysics applied to Hydrogeology. 